\title{
HARGA DIRI PADA ORANG TERKONFIRMASI POSITIF HIV DI TAHUN PERTAMA
}

\author{
Self-Esteem of People Confirmed HIV Positive in the First Year
}

\author{
Gede Arya Bagus Arisudhana ${ }^{1}$, Ni Kadek Widyantari Giri' ${ }^{2}$ I Ketut Buana Yasa ${ }^{3}$ \\ ${ }^{1}$ Departemen Keperawatan Medikal Bedah, STIKES Bina Usada Bali, Badung, Bali, Indonesia \\ ${ }^{2}$ Mahasiswa Program Studi S1 Keperawatan, STIKES Bina Usada Bali, Badung, Bali, Indonesia \\ ${ }^{3}$ VCT Sekar Jepun, RSD Mangusada, Badung, Bali, Indonesia \\ Korespondensi : aryabagus08@gmail.com
}

\begin{abstract}
ABSTRAK
Harga diri merupakan sebuah komponen penting dalam kehidupan orang dengan HIV/AIDS. Harga diri dapat berpengaruh terhadap kualitas hidup orang dengan HIV/AIDS. Tujuan dari penelitian inin adalah untuk melakukan penelusuran tentang harga diri pada orang terkonfirmasi positif HIV di tahun pertama. Desain penelitian ini menggunakan pendekatan studi deskriptif. Populasi terjangkau dalam penelitian ini adalah seluruh orang dengan HIV/AIDS yang menjalani pengobatan di RSD Mangusada. Jumlah sampel dalam penelitian ini sebanyak 44 orang dengan teknik pengambilan sampel menggunakan purposive. Pengumpulan data harga diri menggunakan kuisioner Rosenberg Self Esteem Scale. Analisa data menggunakan uji univariat. Hasil penelitian ini menggambarkan sebagian besar orang dengan HIV di tahun pertama berada pada kategori harga diri rendah 23 (52\%), rata-rata usia responden adalah 33,27 tahun, didominasi oleh laki-laki sebanyak 30 (68\%), tingkat pendidikan responden sebagian besar SLTA 27 (615), serta didominasi oleh responden yang sudah menikah 37 (84\%). Temuan pada penelitian menjelaskan bahwa harga diri pada orang terkonfirmasi positif HIV di tahun pertama sebagian besar berada pada kategori rendah. Untuk itu identifikasi yang dilakukan sejak dini perlu dilakukan guna kefektifan pemberian asuhan keperawatan.
\end{abstract}

Kata Kunci: harga diri, HIV, AIDS

\begin{abstract}
Self-esteem is an important component in the lives of people with HIV / AIDS. Self-esteem can affect the quality of life people with HIV / AIDS. The aim of this study was to investigate self-esteem on people confirmed HIV positive in the first year. This research design uses a descriptive study approach. The affordable population in this study were all people with HIV / AIDS undergoing treatment at RSD Mangusada. The number of samples in this study were 44 people with a purposive sampling technique. The collection of self-esteem data used the Rosenberg Self Esteem Scale questionnaire. Data analysis using univariate test. The results of this study illustrate that most people with HIV in the first year are in the low self-esteem category $23(52 \%)$, the average age of the respondents is 33.27 years, dominated by men as much as $30(68 \%)$, the education level of the respondents most of them were senior high school 27 (615), and dominated by married respondents 37 (84\%). The findings in the study explain that the self-esteem on people people confirmed HIV positive in the first year mostly in the low category. For this reason, early identification needs to be done for the effectiveness of providing nursing care.
\end{abstract}

Keywords: self-esteem, HIV, AIDS 


\section{PENDAHULUAN}

HIV/AIDS telah menjadi infeksi penyakit yang bersifat progresif dan fatal menjadi penyakit kronis dalam tiga dekade terakhir (Deeks, Lewin, \& Havlir, 2013). Dilaporkan jumlah orang dengan HIV pada tahun 2017 mengalami peningkatan mencapai 36.9 juta jiwa. Di area AsiaPasifik, Indonesia menjadi negara dengan jumlah kedua terbanyak penyumbang kasus infeksi baru HIV dengan persentase mencapai $18 \%$. Orang dengan HIV di Indonesia mengalami stigma dan diskriminasi, tercatat hingga tahun 2017 mencapai 62,8\% (Joint United Nations Programme on HIV and AIDS, 2018). Isolasi sosial yang diakibatkan oleh stigma dan diskriminasi dapat berakibat pada harga diri rendah yang dirasakan oleh orang dengan HIV (Halli et al., 2017).

Harga diri merupakan sebuah komponen penting dalam konsep diri seseorang, khususnya bagi orang dengan HIV/AIDS (ODHA). Harga diri berperan penting dalam meningkatkan dan menjaga harapan individu terkait dengan kondisi kesehatannya. Harga diri yang rendah dapat berdampak negatif pada ODHA. Harga diri rendah dapat memungkinkan ODHA tidak melakukan upaya perawatan sehingga dapat memperpendek masa kehidupa ODHA. Penelitian melaporkan tingkat harga diri ODHA berdampak pada kepatuhan mengkonsumsi ARV (Purwaningsih, Asmoro, \& Prastiwi, 2019). Penelitian lain melaporkan harga diri berdampak terhadap kualitas hidup ODHA (Manhas, 2014).

Dilaporkan sebagian besar ODHA yang baru didiagnosis HIV positif merasa putus asa dan berpikir akan segera mati. Dengan dinyatakan positif HIV dapat mengakibatkan individu merubah cara pandang terhadap dirinya (Manhas, 2014). ODHA dapat tidak menghargai dirinya sendiri dan berdampak pada kondisi depresi. Penelitian Fitri (2017), menyebutkan harga diri ODHA akan berdampak pada status depresi. Semakin rendah harga diri ODHA maka akan diikuti dengan semakin tingginya depresi yang dialami. Temuan sebuah penelitian berhasil mengidentifikasi lebih dari 20\% ODHA memiliki harga diri rendah setelah dinyatakan HIV positif (Gausset,
Mogensen, Yameogo, Berthé, \& Konaté, 2012).

Berdasarkan temuan berbagai penelitian yang melaporkan dampak negatif dari rendahnya harga diri ODHA, untuk itu diperlukan identifikasi yang lebih awal terhadap harga diri ODHA yang baru dinyatakan HIV positif. Sehingga dapat dilakukan asuhan keperawatan yang komprehensif untuk tetap menjaga dan meningkatkan harga diri ODHA.

\section{TUJUAN PENELITIAN}

Penelitian ini memiliki tujuan untuk mengidentifikasi harga diri pada orang terkonfirmasi positif HIV di tahun pertama.

\section{METODE PENELITIAN}

Desain

Desain penelitian ini menggunakan pendekatan kuantitatif dengan studi deskriptif.

\section{Populasi dan Sampel}

Populasi terjangkau pada penelitian ini adalah seluruh ODHA yang menajalani perawatan di Poliklinik Sekar Jepun RSD Mangusada Badung Provinsi Bali. Sampel ditentukan berdasarkan teknik nonrandomize dengan metode purposive sampling, dengan jumlah sampel sebanyak 44 orang yang ditentukan menggunakan rumus Slovin. Kriteria sampel dalam penelitian ini adalah memiliki usia 18-45 tahun, tidak menjalani rawat inap, mengalami infeksi oportunistik, bisa membaca, tidak mengalami gangguan indra pendengaran dan pengelihatan.

\section{Tempat dan Waktu Penelitian}

Penelitian ini bertempat di Rumah Sakit Daerah Mangusada Kabupaten Badung Provinsi Bali dan pengumpulan data dilaksanakan selama 4 minggu.

\section{Instrumen dan Prosedur Pengukuran \\ Instrumen yang digunakan dalam pengukuran harga diri ODHA adalah Rosenberg General Self Esteem. Pengukuran dilakukan setelah dilakukan responden yang memenuhi kriteria sampel menandatangani}


lembar persetujuan. Peneliti menjelaskan kuisioner yang digunakan sebagai alat ukur agar responden dapat mengisi sesuai dengan petunjuk. Selanjutnya peneliti melakukan pendampingan pengisian kuisioner untuk membantu jika responden mengalami kesulitan atau merasa kurang jelas dalam pengisian kuisioner.

\section{Analisa Data}

Analisa data menggunakan analisa univariat untuk menentukan distribusi harga diri ODHA dan karakteristiknya.

\section{HASIL PENELITIAN}

Berikut akan ditampilkan hasil penelitian dalam bentuk tabel :

Tabel 1

Karakteristik Responden ( $\mathrm{n}=44)$

\begin{tabular}{|c|c|c|c|}
\hline Variabel & $f(\%)$ & $\begin{array}{l}\text { Min- } \\
\text { Max }\end{array}$ & $\begin{array}{l}\mathrm{SD} \pm \\
\text { Mean }\end{array}$ \\
\hline Usia & & $26-45$ & $\begin{array}{l}5.9 \pm \\
33,27\end{array}$ \\
\hline \multicolumn{4}{|l|}{ Jenis Kelamin } \\
\hline Laki-Laki & $30(68)$ & & \\
\hline Perempuan & $14(32)$ & & \\
\hline \multicolumn{4}{|l|}{ Pendidikan } \\
\hline \multicolumn{4}{|l|}{ Terakhir } \\
\hline Tidak Sekolah & $2(4.5)$ & & \\
\hline$S D$ & $6(14)$ & & \\
\hline SLTP & $6(14)$ & & \\
\hline SLTA & $27(61)$ & & \\
\hline Diploma & $2(4.5)$ & & \\
\hline Perguruan Tinggi & $1(2)$ & & \\
\hline \multicolumn{4}{|l|}{ Status Pernikahan } \\
\hline Menikah & $37(84)$ & & \\
\hline Tidak Menikah & $7(16)$ & & \\
\hline
\end{tabular}

Tabel 1 menunjukkan usia responden minimal 26 tahun dan maksimal 45 tahun dengan rata-rata 33,27. Responden didominasi oleh laki-laki sebanyak 38 $(68 \%$.). Pendidikan terakhir responden didominasi menamatkan SLTA 27(61\%). Selain itu responden didominasi dengan status menikah 37(84\%).

Tabel 2

Karakteristik Harga Diri ODHA (n=44)

\begin{tabular}{cccc}
\hline Harga Diri & $\mathrm{f}(\%)$ & Min-Max & $\mathrm{SD} \pm$ Mean \\
\hline Tinggi & $0(0)$ & $11-25$ & $3.2 \pm 16,1$ \\
Sedang & $21(48)$ & & \\
Rendah & $23(52)$ & & \\
\hline
\end{tabular}

Tabel 2 menampilkan sebaran nilai harga diri dan karakteristik harga diri berdasarkan kategori skor penilaian kuisioner. Diketahui nilai harga diri minima pada skor 11 dan maksimal pada skor 25 dengan rata-rata16,1. Selain itu berdasarkan kategorinya, sebagian besar harga diri ODHA berada pada kategori rendah $23(52 \%)$.

\section{PEMBAHASAN}

Temuan dari penelitian ini diketahui bahwa harga diri ODHA berada pada kategori sedang $21(48 \%)$ dan pada kategori rendah 23(52\%). Harga diri didefinisikan sebagai sebuah penerimaan diri. Seorang yang memiliki harga diri tinggi akan melakukan evaluasi diri secara positif dan dapat berkomunikasi secara efisien (Hemati \& Kiani, 2016). ODHA dengan harga diri yang rendah akan melakukan evalusi diri secara negatif jika dibandingkan dengan ODHA yang memiliki harga diri dengan tingkat sedang. Pasien dengan harga diri yang rendah akan berfokus pada poin negatif yang ada dalam dirinya (KorwinPiotrowska, Korwin-Piotrowska, \& Samochowiec, 2010).

Harga diri yang rendah pada pasien dengan masalah kesehatan yang kronis akan berdampak negatif pada hubungan interpersonal pasien, pikiran, perasaan dan peran fungsi pasien (Korwin-Piotrowska et al., 2010). Harga diri memiliki peran yang unik pada pasien kronis karena akan berbanding lurus dengan kualitas hidup pasien (Hemati \& Kiani, 2016). Jika pasien memiliki harga diri tinggi maka kualitas hidup ODHA akan semakin baik. Telah banyak bukti empiris dari berbagai penelitian terkait harga diri pasien dengan penyakit kronis, menemukan bahwa harga diri yang rendah pada pasien akan berpengaruh terhadap aspek bio-psiko-sosiospiritualnya (Juth, Smyth, \& Santuzzi, 2008).

Pengamatan yang dilakukan peneliti pada respon responden dalam menjawab penyataan tentang harga diri, ditemukan sebagian besar (64\%) responden memberikan respon "tidak setuju" pada pernyataan "Saya merasa bahwa diri saya 
cukup berharga, setidaknya sama dengan orang lain". Hal ini sejalan dengan penelitian Manhas (2014) yang menyatakan status HIV positif dapat berdampak pada pola berpikir dan cara pandang pasien terhadap dirinya. Korwin-Piotrowska et al. (2010) menyebutkan pasien dengan harga diri rendah akan menghabiskan waktu yang lebih sedikit untuk memikirkan aspek-aspek positif dalam dirinya.

Temuan lainnya dalam penelitian ini adalah rata-rata usia responden adalah 33, 27 tahun. Orth \& Robins (2014) menyebutkan selama masa anak-anak harga diri seseorang akan relative tinggi, akan mengalami penurunan pada masa remaja, kemudian akan meningkat secara bertahap sepanjang masa dewasa dan akan cenderung mengalami penurunan pada masa lansia. Sesuai dengan hasil penelitian ini, ditemukan bahwa harga diri responden berada pada kategori sedang sebanyak 21 (48\%), meskipun $23(52 \%)$ lainnya berada pada kategori rendah dari 44 orang responden. Menurunnya harga diri pada seseorang pada usia dewasa dengan penyakit kronis dapat disebabkan oleh kondisi HIV/AIDS-nya, stigma dan diskriminasi (Halli et al., 2017).

\section{KESIMPULAN}

Implikasi

Temuan dalam penelitian ini menggambarkan bahwa sebagian besar ODHA mengalami masalah harga diri rendah. Indentifikasi harga diri rendah pada ODHA yang terkonfirmasi positif dilakukan pada tahun pertama dilakukan sebagai bentuk filtrasi pada ODHA dengan resiko masalah psikologis yang lebih berat. Dengan diketahuinya kemungkinan masalah harga diri rendah sejak dini dapat mencegah ODHA jatuh pada kondisi depresi, sehingga penatalaksanaan keperawatan dapat dilakukan secara komprehensif dari aspek biologis, sosial, psikologis, dan spiritual pasien.

\section{Keterbatasan}

Keterbatasan dalam penelitian ini adalah minimnya jumlah pasien dengan HIV infeksi pada usia lanjut, sehingga untuk membandingkan harga diri pasien HIV positif tahun pertama pada lajut usia dengan usia dewasa tidak dapat dilakukan. Penelitian selanjutnya dapat melakukan penelusuran terkait variabel yang berpengaruh pada harga diri ODHA.

\section{DAFTAR PUSTAKA}

Deeks, S. G., Lewin, S. R., \& Havlir, D. V. (2013). The end of AIDS: HIV infection as a chronic disease. The Lancet, 382(9903), 1525-1533.

Fitri, M. (2017). Hubungan Harga Diri dengan Kejadian Depresi pada Orang dengan HIVIAIDS (ODHA) Di Yayasan Sadar Hati Malang. Universitas Brawijaya. Retrieved from http://repository.ub.ac.id/512/1/Mincha tul Fitri.pdf

Gausset, Q., Mogensen, H. O., Yameogo, W. M. E., Berthé, A., \& Konaté, B. (2012). The ambivalence of stigma and the double-edged sword of HIV/AIDS intervention in Burkina Faso. Social Science and Medicine, 74(7), 10371044.

Halli, S. S., Khan, C. G. H., Moses, S., Blanchard, J., Washington, R., Shah, I., \& Isac, S. (2017). Family and community level stigma and discrimination among women living with HIV/AIDS in a high HIV prevalence district of India. Journal of HIV/AIDS and Social Services, 16(1), 4-19.

Hemati, Z., \& Kiani, D. (2016). The relationship between self-esteem and quality of life of patients with idiopathic thrombocytopenic purpura at Isfahan's Sayed Al-Shohada Hospital, Iran, in 2013. International Journal of Hematology-Oncology and Stem Cell Research, 10(2), 79-84.

Joint United Nations Programme on HIV and AIDS. (2018). UNAIDS Data 2018. Geneva.

Juth, V., Smyth, J. M., \& Santuzzi, A. M. (2008). How do you feel? Self-esteem predicts affect, stress, social interaction, and symptom severity during daily life in patients with chronic illness. Journal of Health 
Gede Arya Bagus Arisudhana, dkk: Harga Diri Pada Orang Terkonfirmasi Positif HIV di Tahun Pertama

Psychology, 13(7), 884-894.

Korwin-Piotrowska, K., Korwin-Piotrowska,

T., \& Samochowiec, J. (2010). Self perception among patients with

multiple sclerosis. Archives of Psychiatry and Psychotherapy, 12(3), 63-68.

Manhas, C. (2014). Self-esteem and quality of life of people living with HIV/AIDS. Journal of Health Psychology, 19(11), 1471-1479.

Orth, U., \& Robins, R. W. (2014). Selfesteem development from young adulthood to old age: A cohortsequential longitudinal study. Journal of Personality and Social Psychology, 98, 645-658. Psychological Science, 23, 381-387.

Purwaningsih, P., Asmoro, C. P., \& Prastiwi, Y. A. (2019). Self-esteem and motivation with adherence of people living with HIV/AIDS (PLWHA) in Indonesia with antiretroviral therapy: A cross-sectional study. International Journal of Adolescent Medicine and Health, 1-7. 